\title{
Dystocia Due to Relative Oversized Fetus and fetal maldisposition in a Buffalo
}

\author{
Pravesh Kumar, Amit Sharma, Navneet Vasishta, Shama Khan and Purabi Barman \\ Department of Veterinary Gynaecology and Obstetrics \\ Dr. GC Negi College of Veterinary and Animal Science, \\ CSK Himachal Pradesh Krishi Vishwavidyalaya, Palampur-176 062, (H.P.) India \\ * Corresponding author email: pk9919@gmail.com
}

Received: 25-06-2011, Accepted: 11-07-2011, Published Online: 23-10-2011

doi: $10.5455 /$ vetworld.2011.569-570

Abstract

A primiparous Murrah graded buffalo suffering with dystocia due to relative oversize fetus and fetal maldisposition and its successful management following laparohysterotomy has been described.

Keywords: Dystocia, Fetal maldisposition, Obstetric, Buffalo, Oversized Fetus.

\section{I ntroduction}

Dystocia is one of the most important obstetrical conditions and requires immediate attention by the veterinarians. Bovines are the most commonly affected species with dystocia, which develops when the birth process is hindered by some physical obstacle or functional defects (Srinivas et al., 2007). Dystocia has been classified into maternal and fetal types (Sloss and Dufty, 1980). The oversized fetus can be relative oversized or absolute oversized.

The oversized fetus, a cause of fetal dystocia can be delivered either with by fetotomy or by performing caesarian section depending upon the condition whether the fetus is alive or dead (Arthur, 2001). The incidence of maternal and fetal dystocia was recorded as 59.16 and 40.84 per cent respectively in Murrah graded buffaloes. Out of 40.84 percent fetal dystocia the incidence of oversize fetus was recorded as 22.41 percent. However, the incidence of dystocia due to fetal maldisposition in pluriparous and primiparous Murrah graded buffalo was recorded as 82.22 and $17.78 \%$ by Srinivas et al. (2007). The higher incidence of fetal dystocia in pluriparous buffaloes might be due to oversized fetus and improper fetal alignment within the birth canal during parturition (Holland et al., 1993). The present report describes a case of dystocia due to relative over sized fetus in a Murrah graded buffalo.
\end{abstract}

\section{Case History and Clinical Observation}

A Murrah graded primiparous buffalo weighing about $300 \mathrm{~kg}$, having body condition score 2.5 and aged about 4 years was presented to the veterinary clinical complex of the institution with the history of continuous straining for last 12 hours. The artificial insemination of the animal was done 10 months before. The buffalo firstly handled by local veterinary pharmacist for 3 hours and then buffalo was submitted to the institution. More than 1.5 liters of mustard oil was put into the uterus for lubrication by the local veterinary pharmacist. The water bags were already ruptured. On general examination buffalo appeared normal, alert and active. Feeding, urination, defecation and rumination were normal. The temperature, pulse and respiration rate of the animal were normal. Udder engorgement and relaxation of sacrosciatic ligament were evident. The vulvular lips were congested, edematous due to bad handling.

Per-vaginal examination revealed dead fetus in anterior longitudinal presentation, dorso-sacral position with bilateral knee flexion and downward lodgment of forehead in pelvic brim (Nape posture). Cervix was fully dilated. The uterine cavity was dry and devoid of any lubrication. The maternal pelvis was narrow. The vagina, cervix and uterus were free from lacerations. The fetus was large in size when compared to maternal pelvis.

The case was diagnosed as dystocia due to relatively over sized fetus with bilateral knee flexion and engagement of forehead in pelvic brim.

\section{Handling and Treatment}

Epidural anaesthesia was given to animal by 
using $5 \mathrm{ml} 2 \%$ lignocaine hydrochloride. As uterine cavity was dry so lubrication was done by 3 liters heavy liquid paraffin. Both the fore limbs of the fetus were snared after correction with standard procedure and then repelled back into the abdominal cavity. Thereafter, the head of the fetotome was put just posterior to the caudal border of the mandible in order to cut the head at atlanto-occipital joint by a transverse cut. As the head of the fetus was large and space in the uterus was less for adjustment of the head so fetal head could not be taken out even after applying the traction to the head by fixing the eyehook in the medial canthus of the eye. It was decided to perform laparohysterotomy.

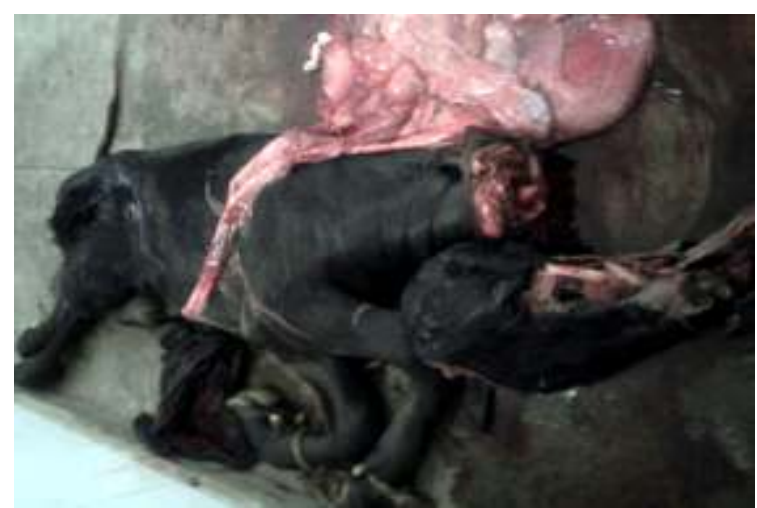

Figure-1. Relative oversized fetus removed after laparohysterotomy.

Laparohysterotomy was done with standard procedure as described by Robert, 1971 by making oblique incision parallel to milk vein. Dead male fetus and amputated head (Figure 1) were removed out from gravid horn. Following laparohysterotomy the buffalo was treated with an antibiotic combination of Amoxycillin and Cloxacillin, injection Intamox ${ }^{\circledR}$ (Intas Pharmaceutical Pvt. Ltd.) 3.0 gm o.i.d for 7 days by I.M. route. Fluid therapy was done with Inj. Intalyte ${ }^{(I n t a s}$ Pharmaceutical Pvt. Ltd.), (combination of $20 \%$ Dextrose with other minerals), 3 liters I.V. infusion for 3 days and a potent NSAID Meloxicam, injection Melonex ${ }^{\circledR}$ (Intas Pharma-ceutical Pvt. Ltd.) $20 \mathrm{ml}$ I.M was given for 5 days. Inj. Lactomag $®$ (Intas Pharmaceutical Pvt. Ltd.) (combination of Calcium borogluconate and Magnesium borogluconate) $450 \mathrm{ml}$ (300 $\mathrm{ml}$ slow I.V. and $150 \mathrm{ml} \mathrm{S.C.)} \mathrm{was} \mathrm{given} \mathrm{only} \mathrm{once} \mathrm{to} \mathrm{increase} \mathrm{the}$ tonicity of muscles and to overcome the deficiency of Calcium and Magnesium. Buffalo was discharged after 3 days with uneventful recovery.

\section{References}

1. Sloss, V. and J. H. Dufty. (1980). Handbook of Bovine Obstetrics. Williams and Wilkins, Baltimore, USA. 208p.

2. Srinivas, M. Sreenu, M., Rani, N. L., Naidu, K. S. and Prasad, V. D. (2007). Studiess on dystocia in graded Murrah buffaloes: a retrospective study. Buffalo Bulletin 26(2): 4045.

3. Roberts, S.J. (1971). A text book of Veterinary Obstetrics and Genital Diseases (Theriogenology) $2^{\text {nd }}$ Edn., C.B.S. publishers and Distributors, New Delhi, pp. 69.

4. Arthur, G.H., D.E. Noakes, T.J. Parkinson and G.C.W. England. (2001). Veterinary Reproduction and Obstetrics, 8th ed. WB Saunders Company Ltd., London. 233.

5. Holland, M. D., N. C. Speer, D. G. LeFever, R. E. Taylor, T. G. Field and K. G. Odde. 1993. Factors contributing to dystocia due to fetal malpresentation in beef cattle. Theriogenology, 39: 899-908. 